\title{
The Development of the Instrument Reasoning Mathematics Courses Set and Logic
}

\author{
Nurhasanah Siregar ${ }^{1}$, Tiur Malasari Siregar ${ }^{2}$, Ade Andriani $^{3}$ \\ \{nurhasanahsiregar@unimed.ac.id ${ }^{1}$, tiur.malasari@gmail.com², adeandriani@unimed.ac.id ${ }^{3}$ \} \\ Department of Mathematics,Universitas Negeri Medan, Jln WilliemIskandart, Medan, Indonesia ${ }^{123}$
}

\begin{abstract}
This research aims to (1) develop an instrument test, (2) describe the procedure for the development of assessment instruments, (3) demonstrate the feasibility of the evaluation instrument. This research was conducted up to a limited trial. This study uses the model Research \& Development (R\&D) consists of five activities, namely (a) introduction, (b) design a draft instrument, (c) instrument development assessment (d) a limited trial, and (e) the revision of the development product. Before a limited trial is conducted,the test is validated to the expert material and evaluation. This reasoning test consists of 7 question. Validation of the items included of content validation regarding the article, construction, and language aspects and the suitability of the problems in the test with indicators obtained from expert considerations. Based on validation questionnaire data by a team of experts, it is known that the developed test instrument is declared feasible in the realm of material, construction, and language.
\end{abstract}

Keywords: Instrument, Reasoning Mathematics ability.

\section{Introduction}

Assessment is a series of activities conducted by teachers to assist students (Beverley \& Education, 2002). Inappropriate test instruments will give incorrect results as well; proper test preparation techniques become a strong foundation for functional evaluation. According to Mardapi (2007) errors in measurement are divided into two types, namely random and systematic errors. Random errors are caused by physical and mental conditions being tested and tested, while systematic errors can be caused by measuring devices. Test making must be able to reduce the mistakes as small as possible from a measurement result produced by a measuring instrument.

According to Gronlund \& Linn (1990), a suitable measuring instrument must have three main characteristics, namely the characteristics of validity, reliability, and usability. Test instruments are one of the things that must be in education. Like the word education without measuring devices such as eating without salt, Teachers must be able to evaluate the learning outcomes that have been carried out. Evaluation is done to make improvements in education, evaluation is intended for teachers and students. This is similar to what Reynolds, Cecil \& Livingston (2009) stated“" educational assessments also can provide important information that helps teachers adjust and enhance their teaching practices. For example, the assessment information can help the teacher determine what teach, how to teach it, and how effective their instruction has been". 
The effectiveness of learning programs must be measurable to be able to see students' understanding of facts, phenomena, principles, concepts, laws, theorems and applications that require the availability of valid and reliable assessments to measure the results and impact of learning carried out assessment has three main functions, namely: (1) knowing the gaps in knowledge possessed by students before learning begins; (2) knowing the learning outcomes of students as a whole; (3) Knowing the strengths and weaknesses of students. The test is a systematic instrument consisting of a set of questions to measure a particular behavior to students with specific categories (Koyan, 2011).

Higher order thinking is one of the priorities in mathematics learning. The demand for mathematics teacher professional competence is that teachers are expected to be able to understand, apply and analyze factual, conceptual, procedural and metacognitive knowledge based on their experience. According to Anderson and Krathwohl (2001), thinking ability is divided into low-level cognitive understanding and higher order thinking. Low-level think is remembering, understanding and applying, and the higher-order thinking is analysis, evaluating and creating. The reasoning is part of a higher order thinking process. The argument is a process or activity of thinking to make conclusions. The sentence above is supported by Kaur's statement (2009) "reasoning is the process of making inferences from a body of information" Similar opinion was expressed by Ball \& Bass (Brodie, 2010) which states that reasoning is an essential ability that is needed to understand mathematical concepts, application in applying work ideas and procedures in mathematics, so that it can construct new knowledge.

Students must have reasoning skills. Improved reasoning ability is developed through the implementation of lectures. To develop reasoning skills, it is necessary to prepare supporting devices. Supporting lecture devices include the Lecture Program Unit (SAP), teaching materials, and reasoning instruments. Supporting tools to be developed must refer to the reasoning ability indicator. The reasoningis divided into two, namely inductive logic and deductive reasoning (Sumarmo, 2012). Inductive reasoning is the ability to conclude in general or individually based on observations with truth values that are true or false. Sumarmo (2012) also said that the knowledge of inductive reasoning belongs to higher-order thinking skills which consist of analogy, generalization, observation, and extrapolation. Still according to the statement of Sumarmo (2012) that deductive reasoning is drawing conclusions based on rules agreed upon with truth values that are right or wrong and not both together

Based on the description, the objective of this research is to produce a mathematical reasoning ability test for logic set subjects. This study hopes to contribute in set and logic courses and provide variations of tests and to know how the validity and characteristics of the reasoning ability tests are developed

\section{Method}

This research is development research, the development model used is a model created by Borg \& Gall (1989). Borg and Gall developed ten steps in development research. Some actions taken in the study are: 1) preliminary research, 2) product planning, 3) initial product development, 4) initial stage trial, 5) product revision, 6) final product.

Development of mathematical reasoning test instruments requires qualitative and quantitative data. The design used is Exploratory Design (Creswell \& Clark, 2007). Subjects were S1 mathematics education students in the first semester who took the 2018 Logic and Set 
matter consisting of 35 students. Research place in one of the LPTK Mathematics Education Study Program in Medan.

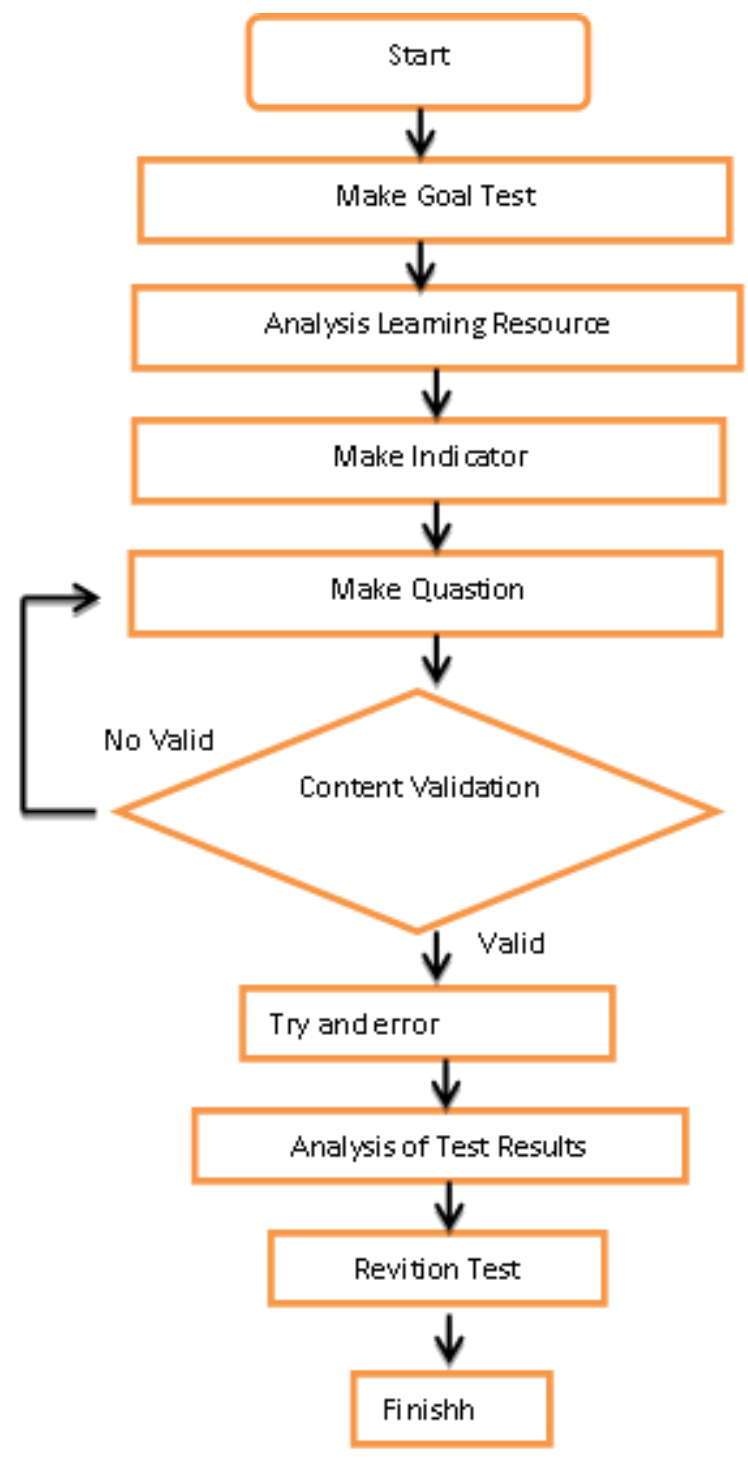

Fig. 1. Scheme of Making Reasoning test 


\section{Result and Discussion}

The resulting product is a mathematical reasoning instrument in the logic set subject namely the question indicator, test instrument, scoring rubric. From the results of the students' answers, it is expected that the improvement of the questions developed. Research data is sourced from expert validation data for feasibility information of test instruments developed, and limited trials (student assessment data on tests developed)

\subsection{Preliminary Studies}

Beginning with the collection of references related to mathematical reasoning tests. Based on the theoretical study described by Sumarmo (2002) indicators of reasoning are: 1) drawing logical conclusions, 2) providing explanations with models, traits and relationships, 3) estimating answers and process solutions, 4) using patterns and relationships to analyze situations or make analogies and generalizations, 5) compile and test conjectures, 6) make counterexamples, 7) follow the rules of inference and check the validity of arguments, 5) compile valid arguments, 9) compile direct, indirect and use mathematical induction. In this section also conducted the selection of the place and the subject of the trial. One of the LPTK in Medan chose the test site. Then observations were made to see the basic abilities of students' mathematical reasoning

\subsection{Plan the Product}

The purpose of this activity is to design an accurate reasoning instrument based on the preliminary stage. The measuring device (instrument test) developed consists of test indicators, questions, and scoring tables. Four steps mustbe done, namely, curriculum analysis, material analysis, student analysis as students and design questions.

\subsubsection{Curriculum Analysis}

The aim is to determine the problems needed in the development of mathematical reasoning tests. The curriculum analyzed was the KKNI curriculum used by the LPTK which was the place of research. Another activity is learning analysis that implements Blended Learning.

\subsubsection{Analysis of Students as Students}

This activity was focused on the first semester students as the subject of the trial because the set and logic were learned in semester I. Each class consisted of 35 students. Based on the results of interviews with students that students' mathematical reasoning has never been explored adequately because the first semester students are new students transitioning from high school

\subsubsection{Material Analysis}

The material analysis is the activity of identifying the main concepts that will be used in designing the students' mathematical reasoning tests. Based on curriculum analysis activities, it was found that the courses that will be used in research based on the KKNI curriculum are 
in the odd semester. The course is a logic set course. Furthermore, some of the subjects were selected from the class. Based on the chosen material, indicators for each question are developed, namely:

a. Presenting mathematical statements verbally, in writing, pictures, and graphics

b. Perform mathematical manipulation.

c. Prepare evidence, provide reasons or evidence for several solutions

d. Make conclusions from the statement

e. Check the validity of the argument

\subsubsection{Designing Questions}

After the physical analysis activity, the next step is to create a reasoning instrument consisting of test indicators, test questions, and scoring guidelines. Questions are designed based on material that has been analyzed and based on students' mathematical reasoning. The researcher developed the test instrument in the form of a description test based on mathematical reasoning indicators. Other activities are compiling test scores and scoring rubrics. Indicator questions are designed based on mathematical reasoning indicators. Scoring rubrics are developed so that other researchers or lecturers are easy to make it easier to provide an assessment of the results of the tests of mathematical reasoning abilities that students have done.

Data collection of test instruments consisting of indicators, test items, scoring. For content validity on the reasoning test developed, it is asked for opinions, suggestions, and input to practitioners or academics in the field of mathematics education and assessment through a validation sheet. Valid on the contents of the mathematical reasoning test is focused on the approval of (a) formulation of indicators and aspects of ability, (b) compiling test items, and (c) rubric scores. Data analysis was carried out to obtain a feasibility assessment that would be used in measuring the reasoning test developed. Data collected from experts were then analyzed to determine the validity of the products produced.

Table 1. Q-Cochran Test Results

\begin{tabular}{ccc}
\hline Statistics & \multicolumn{2}{c}{ Validation } \\
\cline { 2 - 3 } & Performance & Content \\
\hline $\mathrm{N}$ & 6 & 6 \\
Cochran's Q & $2,9001^{\mathrm{a}}$ & $4,800^{\mathrm{a}}$ \\
$\mathrm{df}$ & 7 & 7 \\
Asymp.Sig & 0,650 & 0,321 \\
& One is treated as a success & \\
\hline
\end{tabular}

The results of the consideration given by the validator were analyzed using the Q-Cochran Test. The results of the validation analysis of performance and content are presented in Table 1. From Table 1 it can be seen that Asymp, Sig for performance validation is 0.650 which means that is greater than $\alpha=0.05$ so that it can be stated that all validators that give equal consideration to the performance validity of reasoning instruments. The validity of the contents of the Asymp value, Sig is 0.321 which is also higher than $\alpha=0.05$ so that it can be stated that all validators give equal consideration to the contents of mathematical reasoning instruments for logic set subjects. So that overall it can be said that the device of mathematical reasoning ability in the logic set courses has been validatedregarding performance and content 


\subsection{Limited Trials}

The trial in this study was a small group trial (limited testing). The test results are used to analyze the items and analyze the conceptual understanding. From the scores of students who have done the test then examined to see the validity of the things, test reliability, power difference and difficulty index. The validity of the articleis done by correlating the score of each piece with the total score. From the results of the calculation of the correlation coefficients, each topicis presented in Table 2.

Table 2. Question Validity.

\begin{tabular}{ccc}
\hline question number & correlation coefficient & interpretation \\
\hline 1 & 0,612 & High \\
$2 \mathrm{a}$ & 0,706 & High \\
$2 \mathrm{~b}$ & 0,473 & Quite \\
3 & 0,758 & High \\
4 & 0,353 & Low \\
5 & 0,573 & quite \\
6 & 0,238 & Low \\
7 & 0,802 & Higher \\
\hline
\end{tabular}

Based on the results of the calculation of the correlation coefficients as presented in Table 2 , it can be stated that two questions are developed that have low item validity. So that valid questions based on calculations are five questions. Only five questions can be used to further become a research instrument of mathematical reasoning ability tests on logic set courses.

Next is to determine the reliability of the test. To assess the safety of the test coefficient using the Cronbach Alpha formula. Based on the students' test scores, the calculation of the reliability coefficient is presented in Table 3. From Table 3 it can be seen that Cronbach's alpha for the whole is 0.756 if rounded, Cronbach's alpha is 0.80 so that it can be said that reliability of mathematical reasoning ability tests on logic set subjects classified as high.

Table 3. Reliability Coefficient.

\begin{tabular}{ccc}
\hline Cronbach's Alpha & $\begin{array}{c}\text { Cronbach's Alpha Based on } \\
\text { Standardized Item }\end{array}$ & N of Items \\
\hline 0,756 & 0,801 & 7 \\
\hline
\end{tabular}

From the calculations with Cronbach's alpha can be seen, which items should be deleted, replaced or revised. This is determined by the value of Cronbach's Alpha if Item Deleted, i.e., if the value is more than 0.756 , then the item must be removed replaced or revised.

Table 4. Determine the Item Delete.

\begin{tabular}{cccccc}
\hline No & $\begin{array}{c}\text { Scale Mean If } \\
\text { Item Deleted }\end{array}$ & $\begin{array}{c}\text { Scale Variance } \\
\text { if Item Deleted }\end{array}$ & $\begin{array}{c}\text { Corrected } \\
\text { Item- } \\
\text { TotalCorrectio } \\
\text { n }\end{array}$ & $\begin{array}{c}\text { SquareMultipl } \\
\text { eCorection }\end{array}$ & $\begin{array}{c}\text { Cronbach } \\
\text { Alpha if Item } \\
\text { Deleted }\end{array}$ \\
\hline 1 & 39,386 & 80,673 & 0,567 & 0,278 & 0,715 \\
$2 \mathrm{a}$ & 35,643 & 75,457 & 0,584 & 0,512 & 0,748
\end{tabular}




\begin{tabular}{cccccc}
$2 \mathrm{~b}$ & 34,799 & 94,145 & 0,359 & 1,000 & 0,674 \\
3 & 36,876 & 80,673 & 0,236 & 0,345 & 0,633 \\
4 & 39,386 & 65,367 & 0,658 & 0,289 & 0,799 \\
5 & 41,321 & 60,247 & 0,532 & 1,000 & 0,714 \\
6 & 32,289 & 95,875 & 0,338 & 0,465 & 0,812 \\
7 & 40,654 & 78,346 & 0,567 & 1,000 & 0,701 \\
\hline
\end{tabular}

Table 4 shows that two items have a value higher than 0.756 based on Cronbach's Alpha if Item Deleted calculation, which is number 4 and number 6. So the two questions must be deleted, replaced or revised. Based on the results of the calculations above, it can be said that six questions do not have to be eliminated, replaced or changed, while two items mustbe removed. Because the problems that will be used in the study are only six questions, the two issues are number 4, and question number 6 areremoved. Based on the calculation results of the mathematical reasoning test instrument in the logic set subject issix questions.

The next step is to determine the different power of questions. The power of different questions aims to find out how far the questions developed can distinguish high-ability students from low-ability students. The results of the calculation of the variousinfluence of each item are presented in Table 5

Table 5. Results of Calculation of Different Power Coefficients.

\begin{tabular}{ccccccccc}
\hline Question & $\mathbf{1}$ & $\mathbf{2 a}$ & $\mathbf{2 b}$ & $\mathbf{3}$ & $\mathbf{4}$ & $\mathbf{5}$ & $\mathbf{6}$ & $\mathbf{7}$ \\
\hline diff & 0,67 & 0,25 & 0,45 & 0,56 & 0,17 & 0,77 & 0,15 & 0,55 \\
Inter & $\mathrm{G}$ & $\mathrm{M}$ & $\mathrm{G}$ & $\mathrm{G}$ & $\mathrm{P}$ & $\mathrm{VG}$ & $\mathrm{P}$ & $\mathrm{G}$ \\
\hline
\end{tabular}

After knowing the different power of each question, the next thing to do is to determine the difficulty index of the item. The results of the calculation of the difficulty index of the topics presented in Table 6 can be seen only one problem that is difficult, namely problem number 4 , from the results of the level of difficulty can be concluded that all questions can be used to measure the test of students' reasoning skills in the set of logic

Table 6. Calculation Results of the Problem Index Item.

\begin{tabular}{ccccccccc}
\hline question & $\mathbf{1}$ & $\mathbf{2 a}$ & $\mathbf{2 b}$ & $\mathbf{3}$ & $\mathbf{4}$ & $\mathbf{5}$ & $\mathbf{6}$ & $\mathbf{7}$ \\
\hline dificulty & 0,6 & 0,38, & 0,47 & 0,69 & 0,25 & 0,46 & 0,55 & 0,43 \\
Inter & $\mathrm{m}$ & $\mathrm{m}$ & $\mathrm{m}$ & $\mathrm{m}$ & $\mathrm{d}$ & $\mathrm{m}$ & $\mathrm{m}$ & Sedang \\
\hline
\end{tabular}

\section{Conclusions}

Based on the stages of instrument development, it can be concluded that the instrument of mathematical reasoning ability in the logic set subject is categorized as a valid instrument, meaning that it can be used as an instrument of student mathematical reasoning. Suggestions for further researchers so that researchers can further develop devices for the whole set of logic material. Because this study has my limitations 


\section{References}

[1] Beverley, Bell Formative.: Formative Assessment and Science Education (2002)

[2] Mardapi, D.: Teknik penyusunan instrument tesdan non tes. Yogyakarta: MitraCendikia. (2008)

[3] Gronlund, N. E., \& Linn, R. L.: Measurement and evaluation in teaching $\left(6^{\text {th }}\right.$ ed). New York, NY: Macmillan Publishing Company (1990)

[4] Reynolds, C. R., Livingston, R. B., \&Willson, V. L: Measurement and assessment in education. Upper Sadle River, NJ: Pearson Education, Inc (2009)

[5] Koyan, I Wayan.: Asesmen dalam Pembelajaran. SIngaraja: Universitas Pendidikan Ganesha Press (2011)

[6] Anderson, L. W., Krathwohl, D. R,: A Taxonomy for Learning, Teaching, and Assessing: a Revision of Bloom's Taxonomy of Educational Objectives. Addison Wesley Longman Inc. (2001)

[7] Kaur, B.: Wildfire safety with wireless sensor networks. EAI Endorsed Transactions on Ambient Systems. pp. 1-11 (2011)

[8]Motaz, A.: Reasoning and communication in mathematics classroom-some "what strategies. $\begin{array}{lllll}\text { Diambil pada } & \text { Tanggal } & 15 & \text { September } & 2018\end{array}$ www.mac.vic.edu.au/files/conferences/2009/16Kaur.pdfBorg. W.R \& Gall, M.D. (1989). Educational Research: An Introduction. New York: Logman (2009)

[9] Sumarmo, U.: Pengembangan Program Pendidikan Matematika Hand-out (tidak Dipublikasikan) (2012)

[10] Brodie, K.: Teaching Mathematical reasoning in a secondary school classroom. New York, NY: Springer Science Business Media, LCC. (2010)

[11] Creswell JW, Clark VLP.: Designing and Conducting Mixed Methods Research. California: Sage, Publication. (2007)

[12] Sugiyono.: Metode Penelitian Pendidikan Pendekatan Kuantitatif, Kualitatif, dan R\&D. Bandung: Alfabeta (2010) 